Beverly Charles Leech

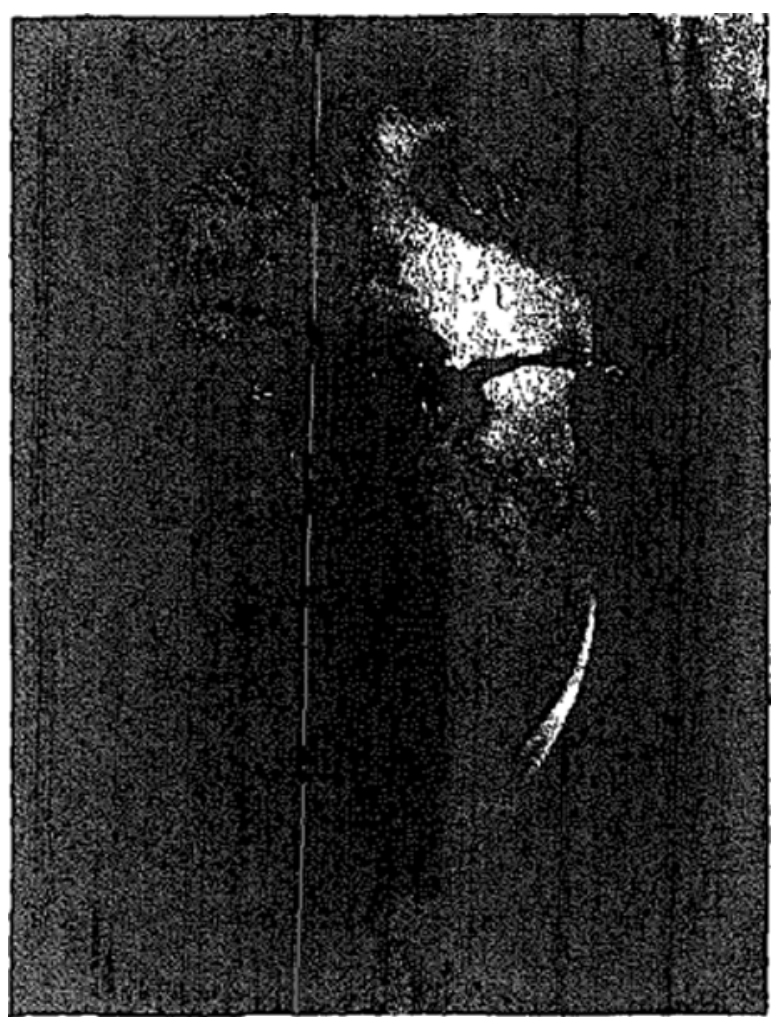

THE DEATH of Dr Beverly Charles Leech occurred in Nanaimo, B.C., on March 10 , 1960, following a cerebral-vásçular accident. " $\mathrm{Bev}$ " Leech was born in Brandon, Man., on May 9, 1898, and received his preliminary education at Central Collegiate, Regina, Sask., and Brandon College, Brandon. Following service in the C.E.F. in World War I, where he attained the rank of lieutenant in the infantry, he returned to Canada and entered McGill University, Twon which he graduated in 1925 with the Degree of M.D., C.M. He established practice in Regina and became Director of Anaesthesia at the Regina General Hospital io 1929, an appointment which he held until 1956. In 1956, he semi-retired to Nanaimo, where he continued pra:tice until his sudden death.

Dr. Leech also served in World War II, with the rank of lieuten.nts-colonel and later colonel in the R.C.A.M.C, as Officer Commanding the 10th Canadian Field Ambulance, 1939-1942; Officer Commanding No. 5 Canadian General Hospital, 1942-1944; and Assistant Durector Medical Services, 2nd Canadian Division, 1944. 
Honours, relating to his war service, were many and included the Order of the British Empire, Canadian Efficiency Decoration, Canadian Forces Decoration, and the Legion d'Honneur (France).

Honours bestowed upon Dr. Leech as a specialist in alnaesthesia were also many and international, and his associations with anaesthetic societies were numerous: Honorary Fellow of the Association of Anaesthetists of Great Britain and Ireland, 1942; Honorary Member of the Section of Anaesthetists of the Royal Society of Medicine, 1942; Fellow of the Faculty of Anaesthetists of the Royal College of Surgeons, 1950; Charter Member of the American Society of Anesthesiologists, 1937; American Board of Anesthesiology, 1939; Fellow of the International College of Anesthesiologists, 1936; Certified Specialist of the Royal College of Physicians and Surgeons of Canada, Anaesthesia, 1943; Charter Member of the Canadian Anaesthetists' Society, President, 1948-9, and Life Member, 1956; Charter Member of the Anaesthetists' Travel Club, which later became the Academy of Anesthesiology.

A pioneer of Canadian anaesthesia has departed. His many international associations have ended. Those of us who were privileged to know Bev Leech, are deeply grieved. He was ever willing to help and sponsor the younger members of his specialty. The Canadian Anaesthetists' Society, the Saskatchewan Bivision, and the British Columbia Division have lost a distinguished member.

To his widow, Elsie, and son, Beverly, Jr., we offer our sincere sympathy.

H.B.G.

\section{AN Appreciatión}

Bev Leech was one of the historic names in Canadian anaesthesia. At a time when few others were interested, he was a leader in the fields of teaching, research, and medical organization and economics. During the difficult years of the 1930's he stood fast against all the storms which swirled around him and continued to demonstrate that good anaesthesia was one of the fundamental concomitants of good medicine. He was not only a good anaesthetist but also a good doctor and a good citizen.

When the war came in 1939 Bev Leech unhesitatingly offered his services, and served throughout those long years in positions of great stress and responsibility. He returned to more hard work in anaesthesia, and persisted in spite of poor health until he had the satisfaction of seeing the specialty established on a very firm basis throughout Western Canada.

Every Canadian anaesthetist should say a little prayer of thankfulness to God for having given us Bev Leech as a leader.

HAROLD R. GRIFFITH, M.D. 